\title{
Factors that Affect the Satisfaction of Viewers Watching TVRI
}

\author{
Muhammad Robitho Rochim ${ }^{1}$, Idqan Fahmi ${ }^{2}$, Siti Jahroh ${ }^{3}$ \\ ${ }^{1,2,3}$ School of Business, IPB University, Gedung SB-IPB, Jl. Raya Pajajaran, Kota Bogor, Jawa Barat 16128 \\ Corresponding Author: Muhammad Robitho Rochim
}

\begin{abstract}
The dynamics of the television industry require each TV station to display the best programming to bind its loyal viewers. TVRI as public television continues to strive to tie the loyalty of viewers by presenting the best programs. However, efforts to present the best programs on TVRI caused some problems later in life. This study aims to analyze TVRI audience satisfaction based on TVRI viewers' direct assessment, by measuring satisfaction levels, analyzing factors that affect satisfaction, and analyzing TVRI audience performance levels and interests. The indicators used to measure satisfaction in this study are program, motivation fulfillment, broadcasting quality, and program packaging. The results showed that respondents were satisfied with TVRI's performance with a satisfaction rate of $88.82 \%$. Factors that significantly affect satisfaction are motivational fulfillment and program packaging. Meanwhile, although the program is a product sold by TV stations, in this study the program had no effect on viewer satisfaction. The main focus that must be improved by TVRI is the packaging of the program, which is the form of studio set display, supporting properties, and presenters. TVRI must also adapt to the needs of the audience in packaging the show, namely with the latest look, fresh and innovative creative ideas to provide a new experience for the audience, not only the broadcast of nostalgic programs that are repackaged, in order to achieve the target audience segment.
\end{abstract}

Keywords: Factors, TVRI, Viewer Satisfaction

\section{INTRODUCTION}

Television is an audiovisual media that is still chosen to be the main source for people who want to get information in the form of news and entertainment based on Nielsen's study (2018), Indonesian viewers spend up to five hours watching TV and spend up to three hours surfing the internet. Since the government made it easier to establish a private television industry license, the broadcasting media industry in Indonesia has undergone a change into a managed industry based on a business approach by relying on advertising revenue to maintain the continuity of its industry. The high competition in the TV industry makes TV media owners have to think of the right competing strategies.

Based on Government Regulation of the Republic of Indonesia Number 13 of 2005 concerning Public Television Broadcasting Institutions of the Republic of Indonesia, in Chapter II, Article 4, it is stated that TVRI has the task of providing information services, education, healthy entertainment, social control and adhesive, as well as preserving the nation's culture for the benefit of all levels of society through the implementation of television broadcasting that reaches all regions of the Unitary State of the Republic of Indonesia. TVRI is not required to pursue ratings and shares in the programs presented, but that does not mean TVRI does not broadcast quality programs.

In the last two years TVRI has made a number of improvements. At its peak 
TVRI conducted a rebranding in March 2019. TVRI's rebranding includes changing the logo, and improving the screen display by airing flagship programs. The rebranding succeeded in restoring the level of public trust, especially third parties who plan to cooperate with TVRI. Rebranding also managed to lift TVRI's rating and share throughout 2019, when compared to 2018. TVRI's rating is at 0.50 until the end of 2018, being above one, even reaching above two point five in 2019 (Figure 1).

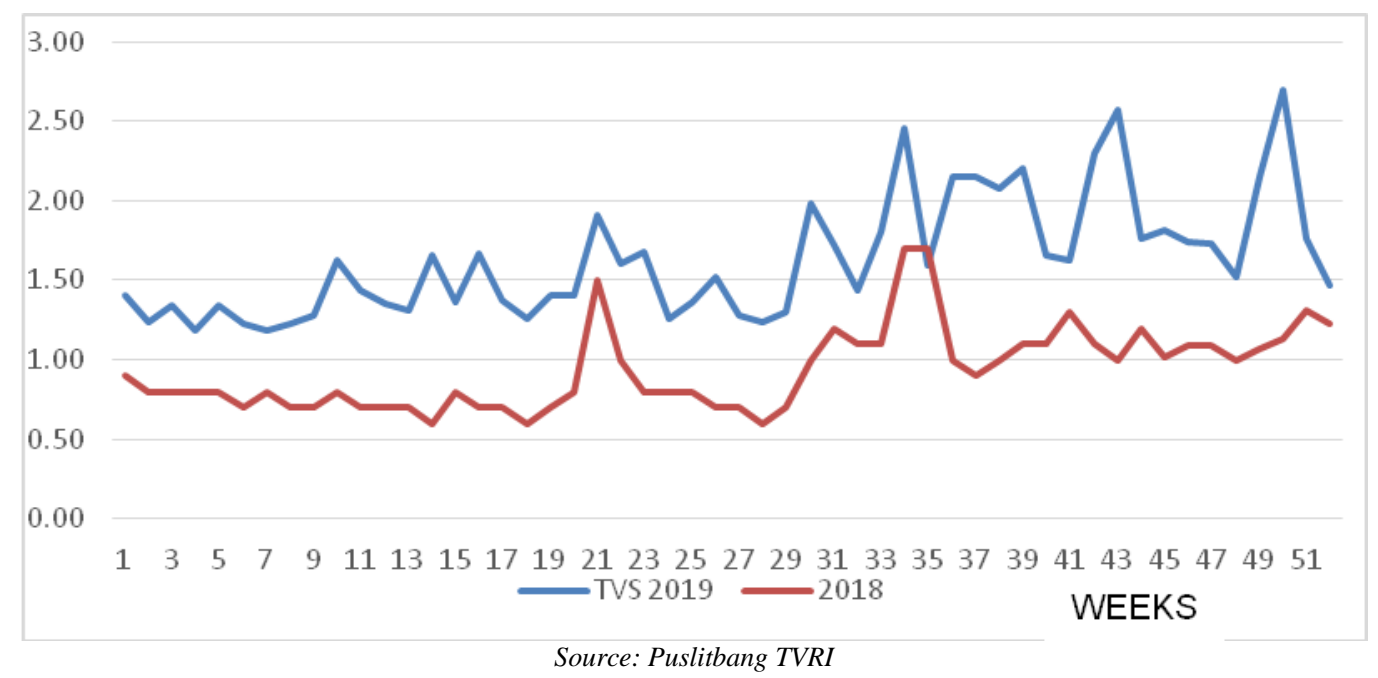

Figure 1 TVRI Rating \&Share Chart 2018-2019

Efforts to repair the screen that had been done by TVRI had raised pro-cons because it was considered to waste the budget for the purchase of expensive programs and progran that aired considered incompatible with the identity of the nation. Based on the description above, it is important for TVRI to understand and analyze the factors that can affect audience satisfaction, because it is the audience who actually know the extent of the need they are looking for with the reality they get from the shows currently presented by TVRI.

Various studies on television audience satisfaction have been conducted. One of them is Gunawan's research (2016) which revealed that viewers get satisfaction with the fulfillment of the element of satisfaction in information indicators, personal identity, integration and social interaction. Albab (2015) stated, audience satisfaction is fulfilled by fulfilling the motivation of watching. Rini (2014) revealed that the factors that dominantly affect audience satisfaction are news content and event packaging. Another study conducted by Giantika (2015) showed that the quality of broadcasting and packaging of programs became factors that influenced viewing satisfaction. Research conducted by Kristanty (2017) on the influence of packaging the show with increased ratings and shares, showed that good program production planning is needed to be able to produce a package of events that attract viewers watching a television show.

Based on these data and facts, it is necessary to conduct a more in-depth study with several objectives, namely (1) analyzing the level of audience satisfaction in watching TVRI, (2) analyzing factors that affect the satisfaction of viewers watching TVRI, (3) formulating strategies in developing programs that can increase the satisfaction of viewers watching TVRI programs. The benefits that can be taken from this research are, this research is expected to be useful for improvement, increase audience satisfaction in watching programs broadcasted by TVRI in the future, and can be used as a reference source for production teams in drawing up strategic plans to improve the quality of broadcast production. 


\section{RESEARCH METHOD The Frame of Thought}

Based on the results of analysis of various theories and the results of previous research related to satisfaction, obtained the frame of thought used in this study which can be seen in Figure 2. Indicators of attributes related to satisfaction levels are analyzed using Structural Equation Modeling (SEM) to determine the causality relationship between existing variables. Important Performance Analysis (IPA) analysis is used as support to know the priority level of improvement of attributes that affect customer satisfaction. Customer Satisfaction Index (CSI) analysis is used to assess satisfaction by considering the level of interest and performance of service providers in consumer perception.

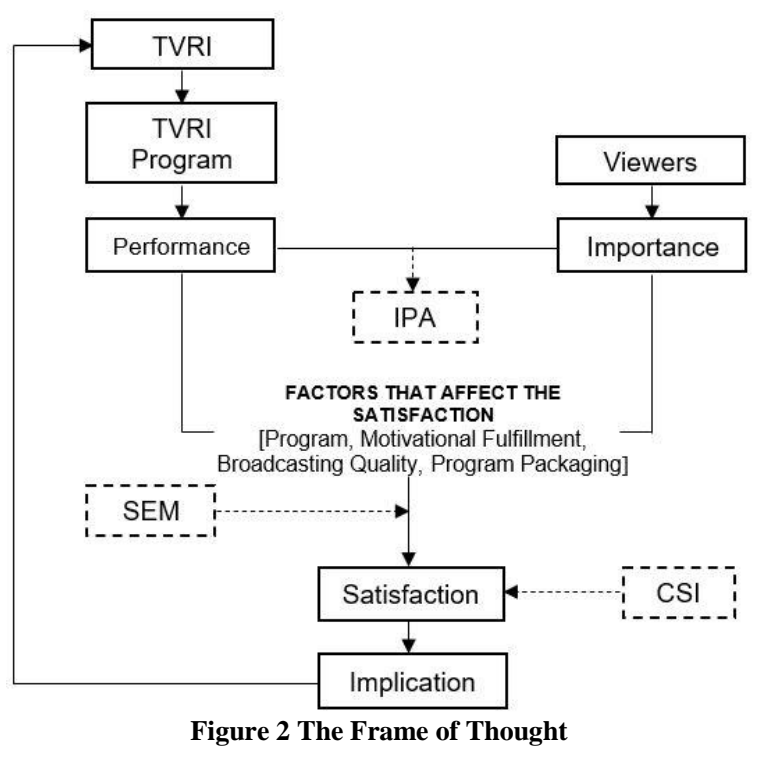

\section{Research Location and Time}

This research was conducted at LPP TVRI Head Office, located at Jalan Gerbang Pemuda no.8 Senayan, Central Jakarta. The research period was conducted in June August 2020, during which time includes proposals, data collection, data processing, data analysis and report preparation.

\section{Data Processing and Analysis Techniques}

The study used a method of nonprobability sampling, in which the probability of each member of the population is unknown. Nonprobability sampling technique used is purposive sampling, meaning the determination of samples by chance, i. e. anyone who is accidentally selected will be made a respondent. The sample of this study amounted to 130 respondents. The basis in the determination of samples is based on several expert opinions including Sugiyono (2013) which states that the sample size in a good study is 30 to 500 respondents. On the other hand, according to Ghozali and Fuad (2005), the minimum sample size for Structural Equation Modelling (SEM) analysis is 100 to 150 samples so that the number of respondents in this study still meets the requirements. The criteria used in this study were viewers who watched TVRI shows approximately once a week, in the last two months, consisting of men and women aged 17 years and above. Respondents will be screened to ensure that they are able to provide a representative answer.

Data Analysis Data Processing techniques and data analysis in this study using descriptive quantitative and qualitative methods. Qualitative approach is done using descriptive analysis that aims to give respondents an idea of TVRI audience satisfaction to the expectations and performance of tvri programs.

In the quantitative approach of the analysis stage conducted, namely, conducting a survey of TVRI audience satisfaction questionnaire in general. The analysis techniques used in this study are cross tabulation analysis, Customer Satisfaction Index (CSI), Structural Equation Modeling (SEM), and Importance Performance Analysis (IPA). Data processing in this study using two analyses, including descriptive analysis and statistics. According to Nazir (2003), the descriptive method of analysis is to make systematic, factual and accurate descriptions of facts and explain the relationship between the phenomena studied. 


\section{Research Variables}

This study has four exogenous variables (Program, Motivation Fulfillment, Presenter Quality, and Program Packaging), and endogenous variables namely satisfaction. Indicators for each variable can be seen in Table 1.

\begin{tabular}{|c|c|c|c|}
\hline \multicolumn{4}{|c|}{ Table 1 Variables and research attributes } \\
\hline No. & Variable & Attribute & Indicators \\
\hline $\mathrm{X} 1$ & \multirow[t]{10}{*}{ Programs (Lamb 2010) } & Program Excellence & TVRI broadcasts exciting Sports matches \\
\hline $\mathrm{X} 2$ & & & TVRI airs interesting Documentary Programs \\
\hline $\mathrm{X} 3$ & & & TVRI airs interesting Educational Programs \\
\hline $\mathrm{X} 4$ & & & TVRI airs interesting News Programs \\
\hline $\mathrm{X} 5$ & & \multirow[t]{2}{*}{ Program Compliance } & $\begin{array}{l}\text { Tvri programs that are broadcast according to the viewer's } \\
\text { favorite }\end{array}$ \\
\hline $\mathrm{X} 6$ & & & $\begin{array}{l}\text { Programs broadcasted by TVRI in accordance with the } \\
\text { wishes of viewers }\end{array}$ \\
\hline $\mathrm{X} 7$ & & Acceptance Rate & TVRI programs have easy-to-understand content \\
\hline $\mathrm{X} 8$ & & \multirow[t]{3}{*}{ Main Functions } & TVRI program provides entertainment benefits \\
\hline X9 & & & TVRI program provides inspiring benefits \\
\hline $\mathrm{X} 10$ & & & TVRI program provides information benefits \\
\hline $\mathrm{X} 11$ & \multirow{12}{*}{$\begin{array}{l}\text { Motivational Fulfillment } \\
\text { (McQuail 2005) }\end{array}$} & \multirow[t]{4}{*}{ Information Fulfillment } & Documentary Program at TVRI adds knowledge \\
\hline $\mathrm{X} 12$ & & & Documentary Program at TVRI adds insight \\
\hline $\mathrm{X} 13$ & & & $\begin{array}{l}\text { Documentary Program at TVRI gives more knowledge } \\
\text { about something }\end{array}$ \\
\hline $\mathrm{X} 14$ & & & I love documentary programs on TVRI \\
\hline $\mathrm{X} 15$ & & \multirow[t]{4}{*}{ Personal Identity } & Education program at TVRI to support personal values \\
\hline $\mathrm{X} 16$ & & & $\begin{array}{l}\begin{array}{l}\text { Educational programs at } \\
\text { confidence }\end{array} \\
\end{array}$ \\
\hline $\mathrm{X} 17$ & & & $\begin{array}{l}\text { Educational programs at TVRI can provide an exemplary } \\
\text { model of behavior }\end{array}$ \\
\hline $\mathrm{X} 18$ & & & I love the Educational Program at TVRI \\
\hline $\mathrm{X} 19$ & & \multirow[t]{4}{*}{ Social Integration and Interaction } & $\begin{array}{l}\text { Tvri's News Program provides knowledge related to social } \\
\text { empathy }\end{array}$ \\
\hline $\mathrm{X} 20$ & & & $\begin{array}{l}\text { News Programs at TVRI can be a conversational material in } \\
\text { the surrounding environment }\end{array}$ \\
\hline $\mathrm{X} 21$ & & & $\begin{array}{l}\text { TVRI News Program becomes a guideline for behaving in } \\
\text { the community }\end{array}$ \\
\hline $\mathrm{X} 22$ & & & I love TVRI News Program \\
\hline $\mathrm{X} 23$ & & \multirow[t]{4}{*}{ Entertainment } & $\begin{array}{l}\text { TVRI Sports Program becomes a means of detachment } \\
\text { from problems }\end{array}$ \\
\hline $\mathrm{X} 24$ & & & TVRI Sports Program becomes a free time filler \\
\hline $\mathrm{X} 25$ & & & TVRI Sports Program becomes a means of entertainment \\
\hline $\mathrm{X} 26$ & & & I love TVRI Sports Program \\
\hline $\mathrm{X} 27$ & \multirow{5}{*}{$\begin{array}{l}\text { Broadcasting Quality } \\
\text { (Kombaitan 2013) }\end{array}$} & \multirow[t]{3}{*}{ Transmittance } & TVRI broadcasts have a sharp image display \\
\hline $\mathrm{X} 28$ & & & TVRI broadcast has clear sound \\
\hline $\mathrm{X} 29$ & & & TVRI has a wide broadcast coverage \\
\hline $\mathrm{X} 30$ & & \multirow[t]{2}{*}{ Event patterns } & TVRI has a clear pattern of shows \\
\hline $\mathrm{X} 31$ & & & Tvri program airtime according to audience genre \\
\hline $\mathrm{X} 32$ & \multirow{4}{*}{$\begin{array}{l}\text { Program Packaging (Morrisan } \\
\text { 2015) }\end{array}$} & \multirow[t]{2}{*}{ Presenter / Host } & TVRI presenters look great in overall fashion and make-up \\
\hline $\mathrm{X} 33$ & & & TVRI presenter looks smart in hosting the show \\
\hline X34 & & \multirow[t]{2}{*}{ Set Studio } & TVRI program features studio settings with a modern look \\
\hline $\mathrm{X} 35$ & & & TVRI program displays appropriate supporting properties \\
\hline Y1 & \multirow{3}{*}{$\begin{array}{l}\text { Satisfaction } \\
\text { (Rangkuti 2008) }\end{array}$} & \multirow{3}{*}{$\begin{array}{l}\text { Evaluation between importance } \\
\text { and performance }\end{array}$} & Desire to always want to watch TVRI programs (Loyalty) \\
\hline $\mathrm{Y} 2$ & & & $\begin{array}{l}\text { Recommend watching TVRI programs to others (Word of } \\
\text { Mouth) }\end{array}$ \\
\hline Y3 & & & Introduction to the company (Brand Image) \\
\hline
\end{tabular}

\section{Measurement Scale}

This study used the Likert measurement scale. The questions in the questionnaire were made in the form of a Likert scale to determine the consumer's assessment of MotivationAl Fulfillment, Broadcasting Quality, and Event Programs. Sumarwan (2017) states that the Likert scale is a scale used to measure one's attitudes, opinions and perceptions about a phenomenon or issue. The Likert scale used is strongly agreed (5), agreed (4), disagreed (3) disagreed (2), strongly disagreed (1).

\section{RESULTS AND DISCUSSION Respondent Overview}

The total respondents used in this study amounted to 130 respondents, the 
respondent's profile was broken down based on demographic characteristics such as gender, age, profession, domicile, and duration of watching TV. Of the 130 respondents to the study, 69 respondents $(53 \%) 61$ respondents $(47 \%)$.

The largest number of respondents from the group in the age range of 30-39 years as many as 42 respondents or about $32 \%$, followed by the age range group of 16-29 years as many as 40 respondents or about $31 \%$, the age range group $40-49$ years as many as 22 respondents or about $17 \%$, the age group 50-59 years as many as 19 respondents or about $15 \%$ and the smallest number of the age range group of 60 years and above as many as seven respondents or about $5 \%$.

\begin{tabular}{|c|c|c|c|c|}
\hline \multicolumn{5}{|c|}{$\begin{array}{l}\text { Table } 2 \text { Classification of respondents based on the frequency } \\
\text { of watching TVRI in a week }\end{array}$} \\
\hline \multirow[t]{2}{*}{ Age } & \multicolumn{3}{|c|}{ Viewing Frequency } & \multirow[t]{2}{*}{ Total } \\
\hline & $\leq 2 \times$ & $5-10 \times$ & $\geq 10 \times$ & \\
\hline $16-29$ & 24 & 16 & - & 40 \\
\hline $30-39$ & 16 & 20 & 6 & 42 \\
\hline $40-49$ & 10 & 9 & 3 & 22 \\
\hline $50-59$ & 10 & 9 & 1 & 20 \\
\hline $60+$ & 2 & 4 & - & 6 \\
\hline \multicolumn{4}{|c|}{ Total } & 130 \\
\hline
\end{tabular}

Based on Table 2, the average respondent watched TVRI less than twice a week, with the largest number of respondents from the age range group of 1629 years, as many as 24 respondents or about 18 percent, while respondents who watched TVRI with a frequency of 5-10 times in the week most of the age range group 30-39 years, that is as many as 20 respondents or about 15 percent, and more respondents who watched TVRI more than 10 times a week as many as 6 respondents or about five percent.

\section{Performance Level of TVRI's Performance Attributes and Audience Interests}

Based on the average value of the importance level value in Table 3 , it can be seen that the respondent's importance value is 5.76, while the average performance level value is 5.23 . This performance value illustrates that TVRI's performance is quite low, because it is below the average value of interest.

Event Packaging Dimension is the dimension that contributes the most to the interests of respondents with an average value of 5.96. Followed by the Broadcasting Quality dimension at an average importance value of 5.91. Event Program dimensions with an average value contribution of 5.76. While the dimension of Motivation Fulfillment is the dimension with the lowest average importance value of 5.66 in providing influence for the satisfaction of TVRI audience respondents.

\begin{tabular}{|l|c|c|}
\hline \multicolumn{3}{|c|}{ Table 3 Attributes of importance and performance } \\
\hline Attributes & $\begin{array}{c}\text { Mean Importance } \\
\text { Score }\end{array}$ & $\begin{array}{c}\text { Mean Performance } \\
\text { Score }\end{array}$ \\
\hline Program & 5,76 & 5,30 \\
\hline $\begin{array}{l}\text { Motivational } \\
\text { Fulfillment }\end{array}$ & 5,66 & 5,28 \\
\hline $\begin{array}{l}\text { Broadcasting } \\
\text { Quality }\end{array}$ & 5,91 & 5,10 \\
\hline Program Packaging & 5,96 & 5,05 \\
\hline Average & $\mathbf{5 , 7 6}$ & $\mathbf{5 , 2 3}$ \\
\hline
\end{tabular}

The dimension that has the highest average value is the Event Program dimension with a value of 5.30. The next dimension is Motivation Fulfillment with a value of 5.28. Broadcasting quality dimension with a performance value of 5.10. While the dimensions of Event Packaging have the lowest performance value of 5.05.

\section{Analysis of The Relationship between Respondent Demographics and Satisfaction Levels}

To see the relationship between respondent demographics and satisfaction level, the hypothesis test is determined as follows:

Ho $=$ No relationship between rows and columns

$\mathrm{Ha}=$ There is a significant relationship between rows and columns

$\alpha=5 \%=0,05$

Decision:

If $\mathrm{p}$-value (Pearson chi-square $<\alpha$, then reject Ho) there is a relationship.

If $\mathrm{p}$-value (Pearson chi-square $>\alpha$, then accept Ho) there is no connection. 
Based on Table 4 it can be seen that, the output of Pearson chi-square on the cross-tabulation analysis of work variables, provides a p-value value (1.2\%) less than $\alpha$ (5\%), then Ho was rejected. It means there is a relationship between work and satisfaction. Respondents with jobs as private employees had the highest satisfaction rate of $17.7 \%$ or as many as 23 respondents. While in other categories there is no relationship between demographics and satisfaction levels.

\begin{tabular}{|c|c|c|c|c|}
\hline \multirow{2}{*}{\multicolumn{2}{|c|}{ Category }} & \multirow{2}{*}{\multicolumn{2}{|c|}{ Satisfaction Level (\%) }} & \multirow{4}{*}{$\begin{array}{c}\text { Pearson chi-square } \\
12,4\end{array}$} \\
\hline & & & & \\
\hline \multirow[t]{2}{*}{ Gender } & Man & 17,70 & 10,80 & \\
\hline & Woman & 24,60 & 14,60 & \\
\hline \multirow[t]{5}{*}{ Age } & $16-29$ & 10,00 & 11,50 & \multirow[t]{5}{*}{8,10} \\
\hline & $30-39$ & 16,90 & 6,90 & \\
\hline & $40-49$ & 8,50 & 3,80 & \\
\hline & $50-59$ & 5,40 & 0,80 & \\
\hline & $60+$ & 1,50 & 2,30 & \\
\hline \multirow[t]{10}{*}{ Occupation } & Not Working Yet & - & 3,10 & \multirow[t]{10}{*}{1,20} \\
\hline & Housewife & 8,50 & 1,50 & \\
\hline & Private Employees & 17,70 & 7,70 & \\
\hline & SOE Employees & - & - & \\
\hline & Student & 2,30 & 3,80 & \\
\hline & Civil Servants & 4,60 & 3,10 & \\
\hline & Army/Police & 0,80 & 1,50 & \\
\hline & Self employed & 5,40 & 1,50 & \\
\hline & Pensioner & 1,50 & - & \\
\hline & Others & 1,50 & 3,10 & \\
\hline \multirow[t]{6}{*}{ Residence } & DKI Jakarta & 11,50 & 4,60 & \multirow[t]{6}{*}{29,60} \\
\hline & Bodetabek & 13,10 & 9,20 & \\
\hline & West Java & 9,20 & 2,30 & \\
\hline & Central Java & 2,30 & 3,80 & \\
\hline & East Java & 5,40 & 3,80 & \\
\hline & Outside Java & 0,80 & 1,50 & \\
\hline \multirow[t]{3}{*}{ Viewing Frequency } & $<2 \mathrm{x}$ & 18,50 & 12,30 & \multirow[t]{3}{*}{9,32} \\
\hline & $5-10 x$ & 20,00 & 11,50 & \\
\hline & $>10 x$ & 3,80 & 1,50 & \\
\hline
\end{tabular}

\section{Respondent's Statement for Overall Satisfaction}

Based on the results of the study of overall respondent satisfaction level in Figure 3, there was a spread of respondents' statements that chose the number 4 with a total percentage of 56.92 or about 74 respondents.

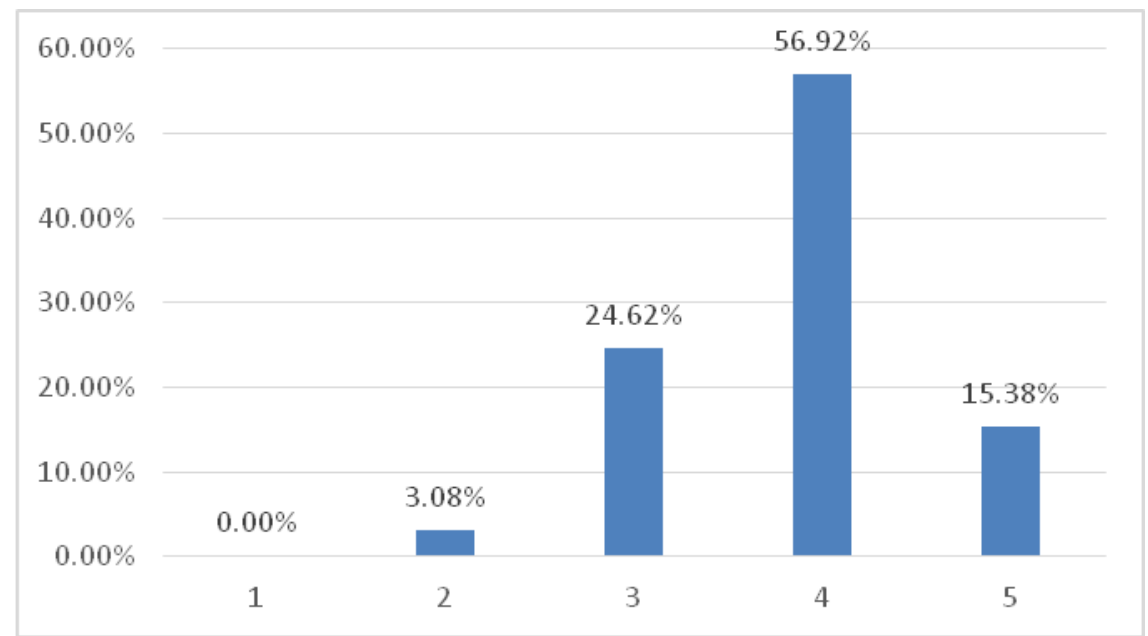

Figure 3 Distribution of respondents based on overall satisfaction level

\section{TVRI Audience Satisfaction Rating}

Based on the calculation of Customer Satisfaction Index (CSI) tvri audience in Table 5 , it obtained a CSI value of $88.82 \%$ or at the interval of CSI value of $81 \%-100 \%$, which means the overall level of tvri audience satisfaction falls into the category of Satisfied. 


\begin{tabular}{|c|c|c|c|c|c|}
\hline \multicolumn{6}{|c|}{ Table 5 Calculation of Customer Satisfaction Index (CSI) tvri audience } \\
\hline \multirow[t]{2}{*}{ No. } & \multirow[t]{2}{*}{$\begin{array}{c}\text { Attribute } \\
\text { Code }\end{array}$} & $\begin{array}{l}\text { Mean Importance Score/ } \\
\text { (MIS) }\end{array}$ & $\begin{array}{c}\text { Weighting Factor/WF } \\
(\%)\end{array}$ & $\begin{array}{l}\text { Mean Satisfaction Score/ } \\
\text { (MSS) }\end{array}$ & Weighting Score/WS \\
\hline & & & {$\left[\mathrm{WF}=\left(\mathbf{M I S} / \sum \mathrm{MIS}\right)\right]$} & & {$[\mathrm{WS}=(\mathrm{MSS} \times \mathrm{WF})]$} \\
\hline 1 & KP1 & 4,29 & 3,05 & 4,40 & 0,134 \\
\hline 2 & KP2 & 4,31 & 3,06 & 4,45 & 0,136 \\
\hline 3 & KP3 & 4,40 & 3,12 & 4,58 & 0,143 \\
\hline 4 & KP4 & 4,28 & 3,04 & 4,57 & 0,139 \\
\hline 5 & SP1 & 3,65 & 2,59 & 4,28 & 0,111 \\
\hline 6 & SP2 & 3,46 & 2,46 & 4,21 & 0,103 \\
\hline 7 & $\mathrm{TP}$ & 4,07 & 2,89 & 4,40 & 0,127 \\
\hline 8 & FU1 & 3,85 & 2,74 & 4,35 & 0,119 \\
\hline 9 & FU2 & 4,07 & 2,89 & 4,55 & 0,132 \\
\hline 10 & FU3 & 4,42 & 3,13 & 4,62 & 0,145 \\
\hline 11 & IN1 & 4,48 & 3,18 & 4,59 & 0,146 \\
\hline 12 & IN2 & 4,46 & 3,17 & 4,65 & 0,147 \\
\hline 13 & IN3 & 4,35 & 3,08 & 4,59 & 0,142 \\
\hline 14 & IN4 & 4,18 & 2,96 & 4,23 & 0,125 \\
\hline 15 & IP1 & 3,94 & 2,80 & 4,39 & 0,123 \\
\hline 16 & IP2 & 3,72 & 2,64 & 4,37 & 0,115 \\
\hline 17 & IP3 & 3,99 & 2,83 & 4,41 & 0,125 \\
\hline 18 & IP4 & 4,02 & 2,86 & 4,18 & 0,119 \\
\hline 19 & IS1 & 4,14 & 2,94 & 4,42 & 0,130 \\
\hline 20 & IS2 & 3,87 & 2,75 & 4,35 & 0,120 \\
\hline 21 & IS3 & 3,90 & 2,77 & 4,38 & 0,121 \\
\hline 22 & IS4 & 4,22 & 3,00 & 4,28 & 0,128 \\
\hline 23 & HI1 & 3,68 & 2,62 & 4,22 & 0,110 \\
\hline 24 & HI2 & 3,97 & 2,82 & 4,24 & 0,119 \\
\hline 25 & HI3 & 4,07 & 2,89 & 4,28 & 0,124 \\
\hline 26 & HI4 & 3,96 & 2,81 & 4,13 & 0,116 \\
\hline 27 & DP1 & 3,84 & 2,72 & 4,60 & 0,125 \\
\hline 28 & DP2 & 3,88 & 2,75 & 4,59 & 0,126 \\
\hline 29 & DP3 & 4,37 & 3,10 & 4,66 & 0,144 \\
\hline 30 & PO1 & 3,77 & 2,68 & 4,51 & 0,121 \\
\hline 31 & $\mathrm{PO} 2$ & 3,77 & 2,68 & 4,43 & 0,119 \\
\hline 32 & PH1 & 4,03 & 2,86 & 4,62 & 0,132 \\
\hline 33 & PH2 & 4,02 & 2,85 & 4,64 & 0,132 \\
\hline 34 & SS1 & 3,69 & 2,62 & 4,54 & 0,119 \\
\hline 35 & SS2 & 3,78 & 2,69 & 4,55 & 0,122 \\
\hline & Total & 140,88 & 100,00 & 155,28 & 4,441 \\
\hline & & $\begin{array}{r}\text { Customer Satisfaction In } \\
\mathrm{CSI}=(\mathrm{WT} / 5) \times 100 \%=(444, \mathrm{r}\end{array}$ & $\begin{array}{l}\text { CSI } \\
\times 100 \%]\end{array}$ & & 88,82 \\
\hline
\end{tabular}

\section{Factors Influencing Audience Satisfaction Watching TVRI}

SEM analysis was used in this study to find out what factors influence television audience satisfaction. Factors that affect the satisfaction of watching Television are program shows, motivation fulfillment, broadcasting quality, and packaging of the event.

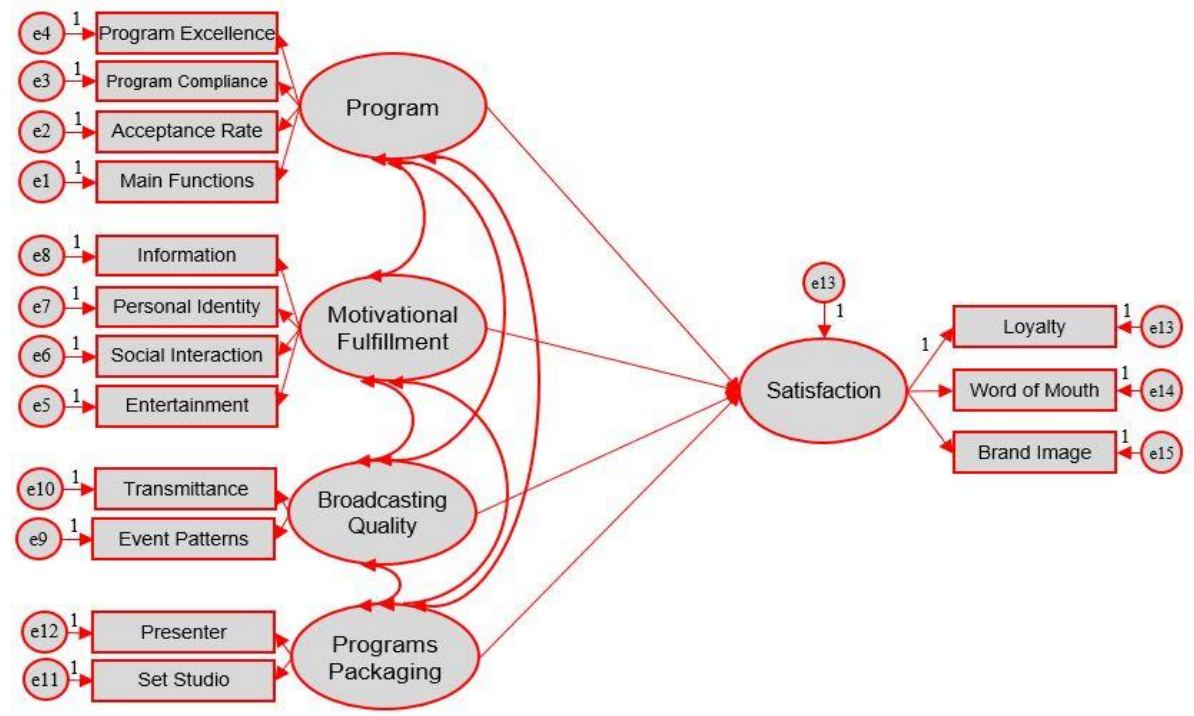

Figure 4 SEM scheme model 


\section{Hypothesis Testing}

\begin{tabular}{|l|c|c|c|c|}
\hline \multicolumn{5}{|c|}{ Table 6 Structural model hypothesis test results } \\
\hline Influence between variables & Path coefficient & S.E. & t-value & $\boldsymbol{p}$-value \\
\hline Program -> Satisfaction Watching & $-0,08$ & 0,058 & $-0,654$ & 0,513 \\
\hline Motivational Fulfillment -> Satisfaction Watching & 0,55 & 0,091 & 2,492 & $0,013^{*}$ \\
\hline Broadcasting Quality -> Viewing Satisfaction & $-0,06$ & 0,092 & $-0,360$ & 0,719 \\
\hline Event Packaging -> Viewing Satisfaction & 0,51 & 0,109 & 2,365 & $0,018^{*}$ \\
\hline
\end{tabular}

Based on Table 6, the results of hypothetical tests on structural models can be seen that there is a significant influence between Motivation Fulfillment and Event Packaging on Viewing Satisfaction, while the variables of Program Acara and Broadcasting Quality do not significantly affect satisfaction. In the Variable Motivation Fulfillment value p-value $(0.013)<0.05$ and the value $t$-value $(2,492)$ $>$ table $t(1,960)$ with a coefficient value of 0.55 then the $\mathrm{H} 0$ hypothesis is rejected and
$\mathrm{H} 1$ is accepted. This means that there is a significant influence of Motivational Fulfillment on Viewing Satisfaction. While in the Event Packaging variable, the p-value $(0.018) \leq 0.05$ and the t-value $(2,365)>$ table $(1,960)$ with a coefficient value of 0.51 , the $\mathrm{H} 0$ hypothesis is rejected and $\mathrm{H} 1$ is accepted. This means there is a significant influence of Event Packaging on Viewing Satisfaction. The results of hypothetical tests on structural models can be seen in Figure 5.

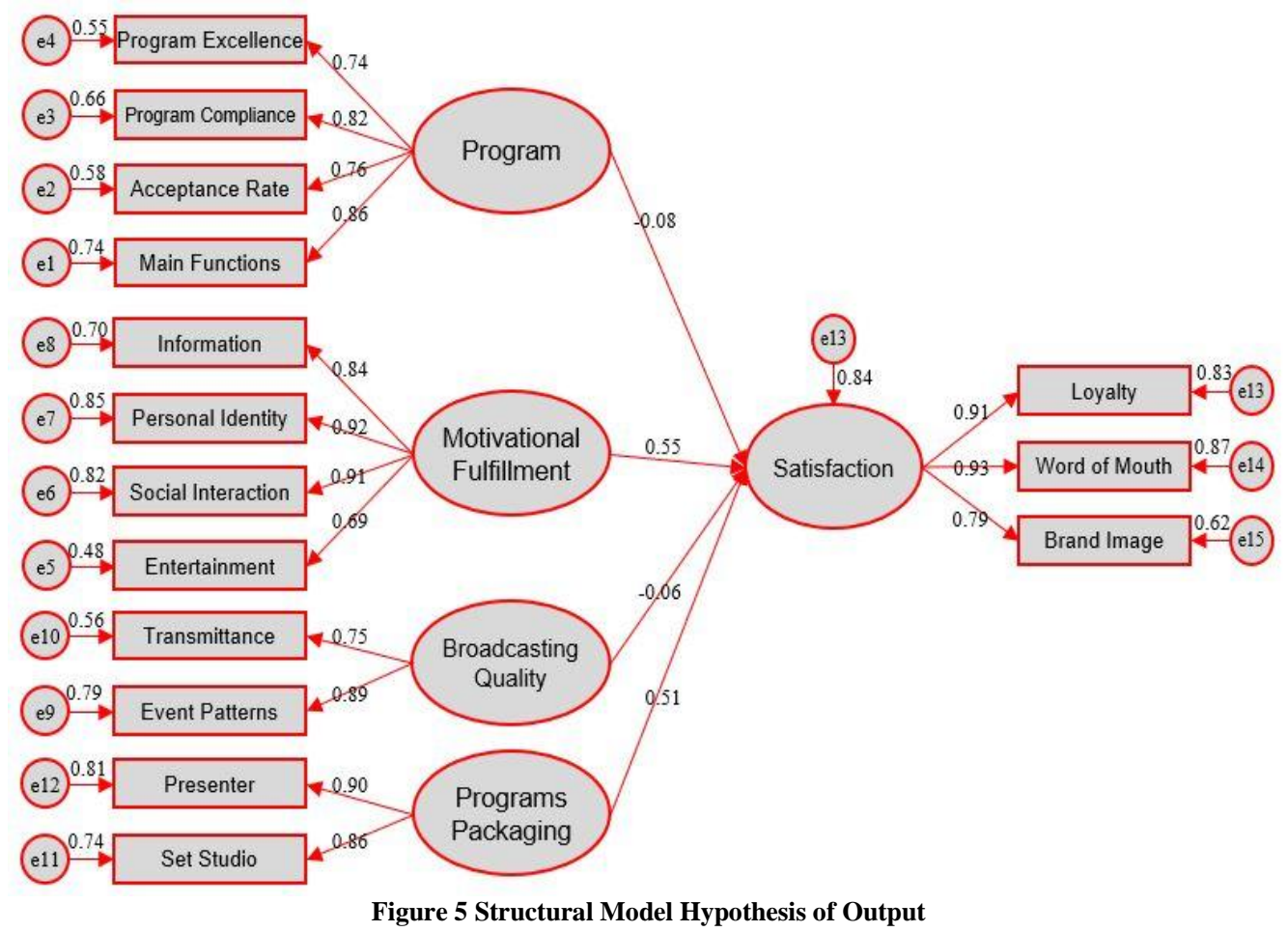

Importance Performance Analysis (IPA) Results

As an effort to increase the satisfaction of TVRI viewers, it is necessary to analyze the IPA to know which variables need to be improved. Importance Performance Analysis in this study is used to map attributes based on their importance and performance. The importance level score and average performance level of each attribute are mapped into a cartesian diagram with the importance level as the $\mathrm{Y}$ axis and the performance level as the $\mathrm{X}$ axis, presented in Table 7 . 


\begin{tabular}{|c|c|c|c|c|c|c|c|}
\hline \multicolumn{8}{|c|}{ Table 7 Average Calculation of TVRI Performance and Audience Interest Assessment } \\
\hline No & Variable & Dimension & Indicators & Importance & Performance & Importance & Performance \\
\hline 1 & \multirow[t]{11}{*}{ Information Fulfillment } & \multirow[t]{3}{*}{ Information } & IN1 & 459 & 448 & 4,59 & 4,48 \\
\hline 3 & & & IN3 & 459 & 435 & 4,59 & 4,35 \\
\hline 4 & & & IN4 & 423 & 418 & 4,23 & 4,18 \\
\hline 5 & & \multirow[t]{3}{*}{ Personal Identity } & IP1 & 439 & 394 & 4,39 & 3,94 \\
\hline 7 & & & IP3 & 441 & 399 & 4,41 & 3,99 \\
\hline 8 & & & IP4 & 418 & 402 & 4,18 & 4,02 \\
\hline 9 & & \multirow[t]{4}{*}{ Social Interaction } & IS1 & 442 & 414 & 4,42 & 4,14 \\
\hline 10 & & & IS2 & 435 & 387 & 4,35 & 3,87 \\
\hline 11 & & & IS3 & 438 & 390 & 4,38 & 3,90 \\
\hline 12 & & & IS4 & 428 & 422 & 4,28 & 4,22 \\
\hline 16 & & Entertainment & HI4 & 413 & 396 & 4,13 & 3,96 \\
\hline 17 & \multirow[t]{4}{*}{ Program Packaging } & \multirow[t]{2}{*}{ Presenter } & PH1 & 462 & 403 & 4,62 & 4,03 \\
\hline 18 & & & $\mathrm{PH} 2$ & 464 & 402 & 4,64 & 4,02 \\
\hline 19 & & \multirow[t]{2}{*}{ Set Studio } & SS1 & 454 & 369 & 4,54 & 3,69 \\
\hline 20 & & & SS2 & 455 & 378 & 4,55 & 3,78 \\
\hline \multicolumn{2}{|c|}{ Average Score } & & & & & 4,403 & 4,024 \\
\hline
\end{tabular}

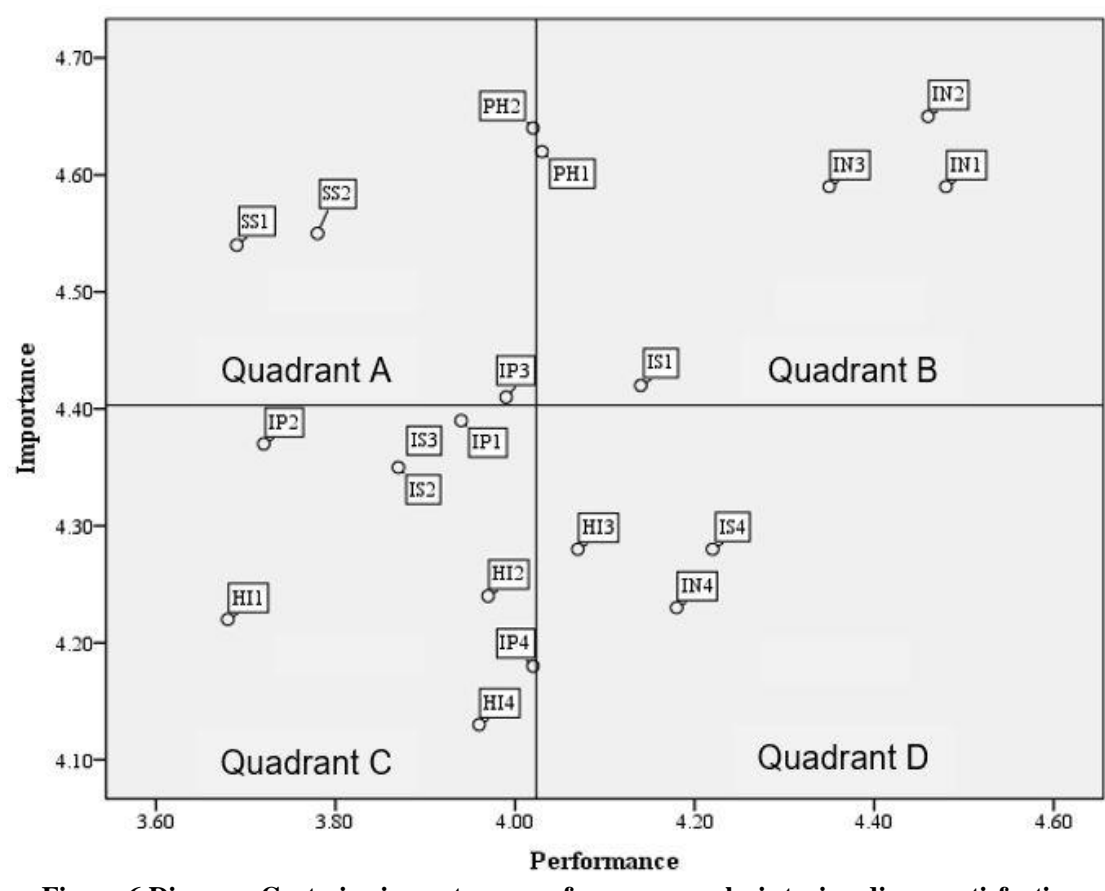

Figure 6 Diagram Cartesius importance performance analysis tvri audience satisfaction

\section{Quadrant A (Main Priority)}

Attributes in quadrant $\mathrm{A}$ are the top priority for TVRI to improve its performance and management is considered to need to allocate resources to improve and improve the performance of these indicators. There are four attributes in quadrant A, namely SS1 (TVRI program displays studio settings with modern look), SS2 (TVRI program displays appropriate supporting properties), $\mathrm{PH} 2$ (TVRI presenters look smart in hosting events), and
IP3 (Educational Programs in TVRI can provide an exemplary model of behavior).

\section{Quadrant B (Maintain Performance)}

The attributes in quadrant $\mathrm{B}$ indicate that the attributes that affect tvri audience satisfaction in this quadrant need to be maintained, because in general the level of implementation is in accordance with the interests of the viewer. Attributes that need to be maintained performance achievements are IN1 (Documentary Program at TVRI 
adds knowledge, IN2 (Documentary Program at TVRI adds insight), IN3 (Documentary Program at TVRI gives more knowledge about a thing), IS1 (News Program at TVRI gives knowledge related to social empathy) and PH1 (TVRI presenters look attractive from fashion and makeup as a whole).

\section{Quadrant C (Low priority)}

Quadrant C contains indicators with relatively low performance, as well as their importance. Improved performance of the attributes in this quadrant is not very important even unnecessary. These attributes, namely IP1 (Educational Program (Learning From Home) in TVRI to support personal values, IP2 (Educational Program at TVRI increases audience confidence), IP4 (I like educational programs in TVRI), IS2 (News Programs in TVRI can be a conversation material in the surrounding environment), IS3 (TVRI News Program becomes a guideline to behave in the community), HI1 (TVRI Sports Program becomes a means of detachment from problems) , HI2 (TVRI Sports Program becomes a free time filler), and HI4 (I like TVRI Sports Program).

\section{Quadrant D (Redundant)}

Quadrant D is a quadrant with attributes that are considered less important. Management needs to transfer resources related to factors in quadrant $\mathrm{D}$ to other factors that require higher handling and need improvement. Based on the results of the study, there are three indicators that are included in quadrant D, namely, IN4 (I like documentary programs on TVRI), IS4 (I like TVRI News Program), and HI3 (TVRI Sports Program becomes a means of entertainment)

\section{Strategies to develop programs that can increase the satisfaction of viewers watching TVRI programs}

Based on the analysis of latent variable-forming indicator variables satisfaction found several variables whose performance should be a priority to be improved. The SS1 (TVRI program displays studio settings with a modern look) and SS2 (TVRI programs display appropriate supporting properties), are two interconnected attributes. Both attributes are related to the studio settings display on TVRI-aired programs and the supporting properties displayed on each show. In improving both attributes, TVRI is advised to pack the show more adaptively according to the needs of the audience that follows the development of the times. TVRI should also think of a pack of events with fresh, innovative concepts and ideas to provide a new experience for its current audience instead of just airing nostalgic events that are repackaged, to target the millennial audience market segment, considering the demographics of Indonesia's population today dominated by millennials.

In terms of improving the attributes of PH2 (TVRI presenters look smart in hosting the show) TVRI is advised to present famous presenters to be able to attract viewers. (Results of interview with Audrey G Tangkudung, Media Practitioner and Editor-in-Chief of Polri TV, 2020). Famous or rising presenters can certainly entice their fans to watch their performances when hosting shows on TVRI. IP3 (Education Program at TVRI can provide an exemplary model of behavior) TVRI is advised to add educational programs that are able to set an example, instill targeted social and moral messages and in accordance with people's lives.

\section{CONCLUSIONS AND SUGGESTIONS Conclusions}

Based on the results of the analysis in the previous chapters and referring to the purpose of research in the introductory chapter, the following conclusions are obtained:

1. TVRI's audience satisfaction rate reaches $88.82 \%$, which means viewers are satisfied with the programs aired by TVRI. 
2. The dimension of motivation fulfillment and packaging of the event are factors that have a significant influence on the satisfaction of viewers in watching TVRI. While the program dimensions of the show and the quality of broadcasting have no significant influence on audience satisfaction.

3. The attributes that are the top priority to be improved or improved performance are tvri program attributes featuring studio settings with modern look, TVRI program displays appropriate supporting properties, TVRI Presenters look smart in hosting events, and Educational Programs in TVRI can provide models of behavior that can be exemplified.

\section{Suggestions}

The results of this study are expected to be used as the basis of the company in producing the program so that the output in the form of the resulting program can increase audience satisfaction because it is able to meet the wishes and passions of the audience.

The suggestion for the development of further research is to evaluate the level of audience satisfaction of one television station by comparing with satisfaction with other television stations. In addition to comparing satisfaction levels with other television stations, in further research it is necessary to evaluate the relationship of the program to audience satisfaction. The number of samples used also needs to be increased, adjusted to the level of diversity of the research population, with the aim of reducing errors in the results of the study.

Acknowledgement: None

\section{Conflict of Interest: None}

\section{Source of Funding: None}

\section{REFERENCES}

1. AC Nielsen Media Research. 2018. Customer Media View 02. Media Audience Measurement. Rating Televisi
Indonesia - Informasi Televisi Indonesia.

2. Albab M, Amiruddin S. 2018. Hubungan Motivasi dan Pola Menonton dengan Tingkat Kepuasan Pemirsa pada Program Berita Topik ANTV. [tesis] Bogor (ID) Institut Pertanian Bogor.

3. Ghozali I, Fuad. 2005. Structural Equation Modeling: Teori, Konsep, dan Aplikasi. Semarang (ID): Badan Penerbit Universitas Diponegoro.

4. Giantika GG. 2015. Pengaruh Kualitas Penyiaran dan Kemasan Program Terhadap Kepuasan Menonton Program Musik Inbox SCTV (Studi Kasus Mahasiswa BSI Pemuda Rawamangun). Jurnal Komunikasi, Volume VI Nomor 2, September 2015.

5. Gunawan L. 2016. Motif dan Kepuasan Masyarakat Surabaya dalam Menonton Program Dialog "Titik Tengah" di Metro TV Jawa Timur. Jurnal ekomunikasi. 4 (1): 1-12.

6. Hafizh A. 2017. Analisis Tingkat Kepuasan Pelanggan PT Tepian Multimedia Samarinda. Jurnal Administrasi Bisnis, Volume 5, No.03.

7. Hatta H, Ardhita F. 2016. Faktor yang mempengaruhi keputusan konsumen menonton program acara Djarum Indonesia Super League di ANTV di provinsi Lampung. Prosiding Seminar Nasional INDOCOMPAC Universitas Bakrie.

8. Kaban SCB. 2018. Motif dan kepuasan menonton video blog di kalangan anak muda kota Denpasar. E-Jurnal Medium. $1(2): 1-8$.

9. Kalebos F. 2016. Faktor-Faktor Yang Mempengaruhi Kepuasan Wisatawan Yang Berkunjung Ke Daerah Wisata Kepulauan. Universitas Sam Ratulangi. Jurnal Riset Bisnis dan Manajemen. 4 (3). 482-502.

10. Linardi LN. 2015. Kepuasan Masyarakat Surabaya Dalam Menonton Tayangan Stasiun Dangdut di JTV, Surabaya (ID). Jurnal E-Komunikasi. 3 (1): 1-11.

11. Mandala L. 2013. Pola dan Kepuasan Khalayak Menonton Televisi Komunitas 
Grabak TV. [tesis]. Bogor (ID). Institut Pertanian Bogor.

12. Mooy RMP. 2015. Motif Dan Kepuasan Pemirsa Surabaya Dalam Menonton Sinetron "Tukang Bubur Naik Haji". Jurnal e-komunikasi. 3 (2): 1-12.

13. Oktamirantika D. 2017. Motif Menonton Program Berita Islami Masa Kini Trans TV Terhadap Tingkat Kepuasan pada Jamaah Masjid Raya Annur di Kota
Pekanbaru. Jurnal Online Mahasiswa. 4 (2): 1-14.

How to cite this article: Rochim MR, Fahmi I, Jahroh S. Factors that affect the satisfaction of viewers watching TVRI. International Journal of Research and Review. 2021; 8(6): 96-107. DOI: https:// doi.org/10.52403/ijrr.20210612 